This PDF is a selection from an out-of-print volume from the National Bureau of Economic Research

Volume Title: Tax Policy and the Economy, Volume 3

Volume Author/Editor: Lawrence H. Summers, editor

Volume Publisher: MIT Press

Volume ISBN: 0-262-06126-0

Volume URL: http://www.nber.org/books/summ89-1

Conference Date: November 15, 1988

Publication Date: 1989

Chapter Title: The Japanese Tax Reform and the Effective Rate of Tax on Japanese Corporate Investments

Chapter Author: John B. Shoven

Chapter URL: http://www.nber.org/chapters/c10947

Chapter pages in book: (p. 97 - 115) 


\section{THE JAPANESE TAX REFORM AND THE EFFECTIVE RATE OF TAX ON JAPANESE CORPORATE INVESTMENTS}

\section{John B. Shoven}

Stanford University and NBER

\section{EXECUTIVE SUMMARY}

Japan is in the midst of reforming its national-level individual and corporation income tax systems. Last year, it abandoned its large system of tax-free savings accounts and lowered individual marginal tax rates. A much more radical proposal is currently being advocated by the government and is well along the way toward passage in the Diet. The new proposal would significantly lower the statutory rate for the corporation income tax, lower individual rates further and increase the tax thresholds, tax capital gains on securities for the first time, and introduce a type of value-added tax. As a package, this would be the most important change in the Japanese tax system since 1950.

This paper presents a brief summary of the Japanese income tax system and the changes in it that have been enacted or proposed. It also

This paper was prepared for the NBER conference "Tax Policy and the Economy" held in Washington, D.C., on 15 November 1988. I am indebted to Tatsu Sakai of the Ministry of Finance, to Kazuo Yagi of the Foundation for Advanced Information and Research (FAIR), Japan, and to Shuzo Nakamura, Chief Economist of the Institute of Fiscal and Monetary Policy, Ministry of Finance, Japan, for sending me materials regarding the Japanese Tax Reform. I also wish to thank Mervyn King for making his working paper on the subject available. 
discusses and evaluates the pressures for reform, both domestic and international. Finally, the paper looks at how the taxation of capital income in Japan has changed since 1980 and how it compares to the U.S. taxation of capital income after our 1986 tax reform. One major finding of the paper is that the effective marginal tax rate on corporate capital income in Japan has increased sharply since 1980, from roughly 5 percent to about 32 percent. This change, which still leaves the marginal taxation on corporate investments somewhat lower in Japan than in the U.S., is due to both changes in the Japanese tax code and the virtual elimination of inflation in Japan.

\section{INTRODUCTION}

Japan is in the midst of reforming its national-level individual and corporation income tax systems. Last year, it abandoned its large system of tax-free savings accounts and lowered individual marginal tax rates. A much more radical proposal is currently being advocated by the government and is well along the way toward passage in the Diet. The new proposal would significantly lower the statutory rate for the corporation income tax, lower individual rates further and increase the tax thresholds, tax capital gains on securities for the first time and introduce a type of value-added tax. As a package, this would be the most important change in the Japanese tax system since 1950.

This paper presents a brief summary of the Japanese income tax system and the changes in it that have been enacted or proposed. It also discusses and evaluates the pressures for reform, both domestic and international. The U.S. Tax Reform Act of 1986, with its low marginal tax rates, is among the forces for change in Japan. Finally, the paper looks at how the taxation of capital income in Japan has changed since 1980 and how it compares to the U.S. taxation of capital income after our 1986 tax reform.

Developments in the Japanese economy are worth monitoring if only because Japan's is the second-largest economy in the world and its economic performance is widely admired. It has achieved high economic growth rates, a recently stable price level, a trade surplus, and a high level of national saving and investment. In previous work (Shoven and Tachibanaki, 1988), I found that in 1980 Japan had a much lower tax wedge between the return on investments and the return enjoyed by investors than had the U.S. That is, in Japan the government took a smaller fraction and the investor a larger fraction of the return on a new marginal investment. Two questions that this paper addresses are whether that lower level of effective taxation on incremental capital in- 
come persists in Japan in 1988 and whether it will continue if the proposed tax reforms are enacted.

\section{THE JAPANESE TAX SYSTEM}

Japan and the U.S. have the lowest overall tax burdens as a percent of gross domestic product (GDP) of the countries listed in Table 1. Japan's figure ( 28.0 percent) is slightly lower than that for the U.S. Japan also generates far less revenue as a fraction of GDP from the household-level income tax than does the U.S. In fact, Japan's revenue from the individual income tax is less than that of any of the other countries except France. Its reliance on sales and consumption taxes is the lowest among the eleven countries. In contrast, its corporation income tax raises the highest fraction of GDP (well over twice the comparable U.S. figure). It is this heavy use of the corporation tax that made my previous result of light taxation of income from new Japanese capital investments surprising.

As in the U.S., there are three levels of taxation in Japan: the national level, the prefecture (state) level, and the municipal level. If we exclude the social security payroll contributions, the individual income tax raised 40.5 percent of the revenue at the national level, whereas the corporation tax raised 30.6 percent. Of the remaining 28.9 percent, liquor taxes accounted for 4.8 percent, gasoline taxes 3.8 percent, and the inheritance and gift tax 2.7 percent. The final 15.6 percent of revenue was raised mainly by a wide variety of excise taxes. Corporate and individual income is subject to taxation at both the prefecture and the municipal levels (primarily according to the "inhabitants tax"). These local governments also raise revenue through property taxes, automobile taxes, an enterprise tax, and a wide array of excise taxes.

The first thing to note about the national-level individual income tax is that the individual is the taxable entity, rather than the household as in the U.S. For the average single-earner household, this difference is not very important. In fact, the tax of most wage earners is automatically calculated through a sophisticated withholding mechanism. Most individuals whose incomes are predominantly wages do not even have to fill out a tax return. However, the individual basis of taxation does open up the possibility of income splitting for self-employed small-businesspeople and those with significant sources of capital income.

The marginal tax rate structures for the national-level individual income tax are shown in Table 2 for 1986, for 1987 (after the September 1987 tax revisions), and for the 1988 proposal of the Ministry of Finance. In 1986, there were fifteen rate brackets, with marginal rates ranging from 10.5 to 70 percent; in 1987, these were replaced with twelve brack- 


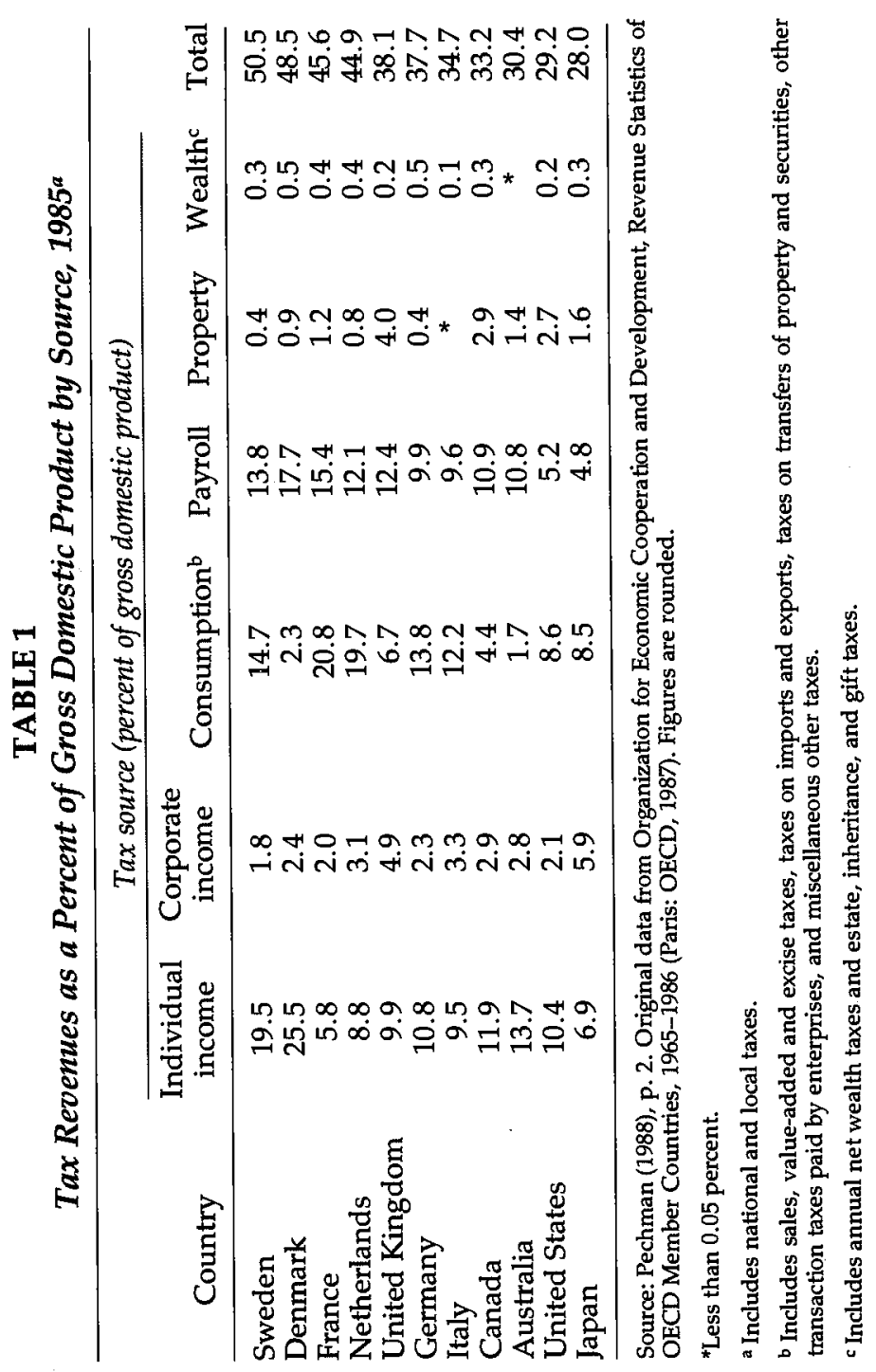


ets, ranging from 10.5 percent to 60 percent; the proposal now under consideration would replace these with five brackets, with marginal tax rates from 10 to 50 percent. The number of rate brackets for the inhabitants tax (local income tax) is proposed to be reduced from 14 (with rates ranging from 4.5 percent to 18 percent) to four (with rates ranging from 5 to 15 percent). The top combined rate was 88 percent in 1986 and would be 65 percent under the current proposal.

The puzzle of why the marginal rates for the individual income tax are relatively high and revenues relatively low is partially answered by the generous levels of the tax thresholds (the level of income below which no tax is paid). Table 3 shows that the threshold level of wage and salary income for a one-earner family of four will have increased by almost 36 percent in two years if the latest proposals are adopted. The proposed tax threshold for a family of four is $¥ 3,198,000$, or $\$ 26,000$, at the current (1988/89) exchange rate ( $¥ 123$ to the dollar), more than twice the tax threshold in the U.S. for a family of the same composition (the sum of the U.S. system's standard deduction and personal exemptions for a family of four was $\$ 8300$ in 1986 and $\$ 12,800$ in 1988). Note that the average annual wage income in Japan is roughly $¥ 4$ million. It appears that the Japanese have used their relatively low reliance on individual income tax sources to increase the progressivity of their tax system rather than to enjoy the efficiency that could have come from lower marginal rates. This feature of relatively high income thresholds is longstanding and was one of the primary reasons that Pechman and Kaizuka (1976) found that only 33 percent of Japanese national income was reported as taxable income in 1970, compared with 59 percent for the U.S. at that time. Despite the high top rates, note that Tables 2 and 3 together imply that under the new proposal a one-worker family of four would remain in the 10 percent national income tax bracket until their earnings reached $¥ 7,162,650$, or $\$ 58,233$. This income level (at which the Japanese rate will jump from 10 to 20 percent) is at least 20 percent higher than the income level for a family of four at which the U.S. rate jumps from 15 to 28 percent. About 90 percent of all workers in Japan will face the lowest marginal rate, and many will remain in the lowest tax bracket for their entire planning horizon. This last feature effectively eliminates the problem of timing income to minimize taxes.

In principle, the Japanese individual income tax system applies to aggregate income (such as interest income, dividend income, rents, business income, wages, retirement income, timber income, and capital gains). In practice, many of these income sources are eligible for special treatment. Retirement income and timber income are always taxed sepa- 


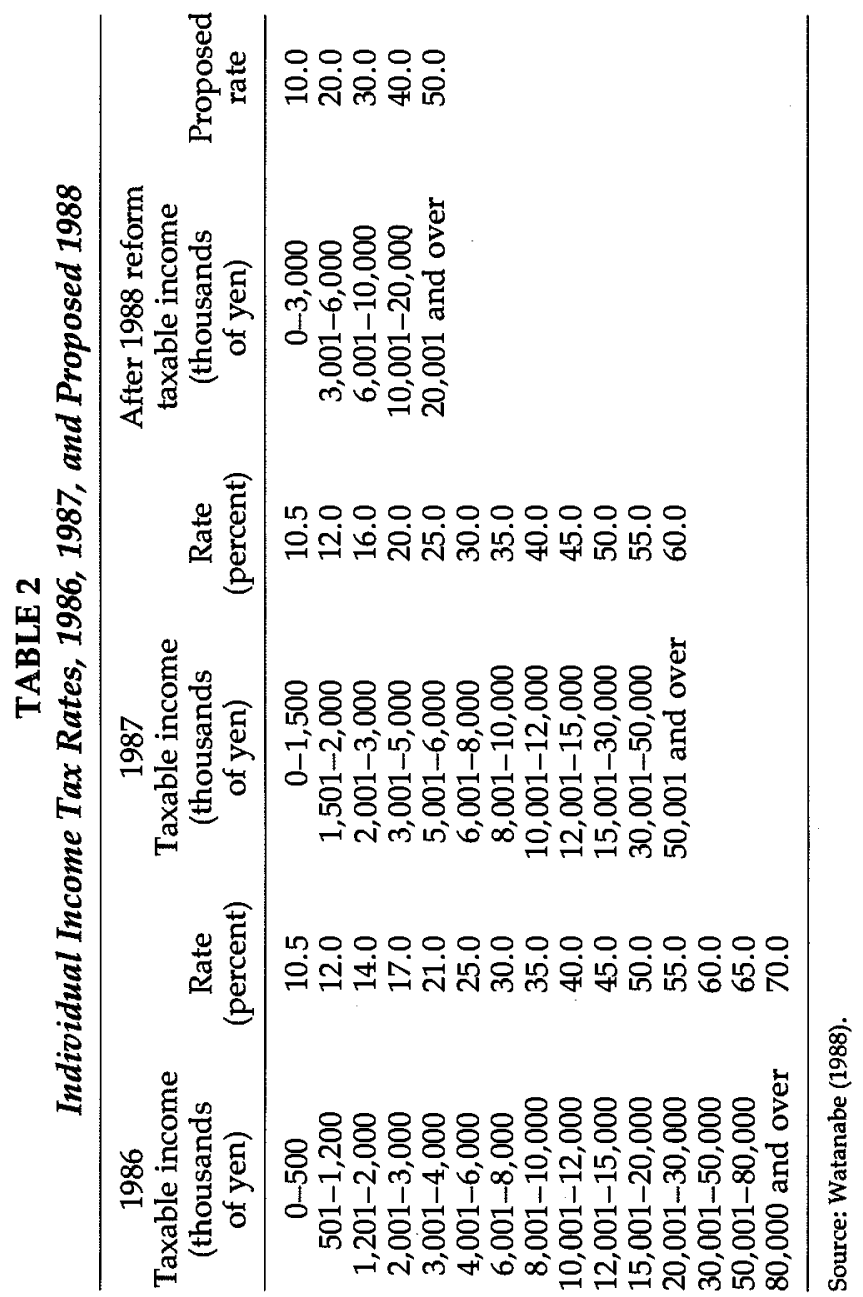


TABLE 3

Income Tax Threshold for a Family of Four (employee, spouse, two children, one between 16 and 22 years old)

\begin{tabular}{lccc}
\hline & $\begin{array}{c}1986 \\
\text { (thousands } \\
\text { of yen) }\end{array}$ & $\begin{array}{c}1987 \\
\text { (thousands } \\
\text { of yen) }\end{array}$ & $\begin{array}{c}\text { After 1988 reform } \\
\text { (thousands } \\
\text { of yen) }\end{array}$ \\
\hline Basic exemption & 330 & 330 & 350 \\
Exemption for spouse & 330 & 330 & 350 \\
Special exemption for spouse & - & 165 & 350 \\
Exemption for children & 330 & 330 & 350 \\
Employment income deduction & 330 & 330 & 450 \\
Deduction of social insurance & 872 & 951 & 1,124 \\
premiums & 165 & 183 & 224 \\
\hline \multicolumn{1}{c}{ Total } & 2357 & 2619 & 3198 \\
\hline
\end{tabular}

Source: Ministry of Finance

a 40 percent of first $¥ 1,650,000$ in salary, plus 30 percent of amount between $¥ 1,650,000$ and $¥ 3,300,000$, plus 20 percent of amount between $¥ 3,300,000$ and $¥ 6,000,000$, plus 10 percent of amount between $¥ 6,000,000$ and $¥ 10,000,000$, plus 5 percent of the amount over $¥ 10,000,000$. The minimum employment income deduction is $¥ 570,000$.

rately, and interest, dividends, and capital gains are often taxed separately at the taxpayer's option.

The treatment of interest income has been among the most generous of these special treatments. Until the September 1987 tax reforms, there were two special features of the law favoring interest income. First, Japanese taxpayers were allowed to have four types of saving plans offering tax-free interest. The types of tax-free interest were

1. Interest accruing from postal savings, if the principal did not exceed $¥ 3$ million.

2. Interest income or distribution of profits from deposits, bonds, and debentures, open-end bond investment trusts, or specific stock investment trusts, if the total amount of principal did not exceed $¥ 3$ million. This provision was called the Small Saving Tax Exemption (Maruyu in common Japanese).

3. Interest on central-government and local-government bonds, not exceeding $¥ 3$ million in total face value.

4. Interest income or distribution of profits received in accounts set up for the formation of employees' assets, particularly for housing and pensions. Various forms of monetary assets are eligible for this exemption. It requires, however, that the employees commit to saving con- 
tracts withholding part of their wages and that the total amount of principal does not exceed $¥ 5$ million.

Summing up these four items, an individual could have had up to $¥ 14$ million $(\$ 113,821)$ in nontaxable forms. If the household had several members, the amount of nontaxable saving could be increased accordingly. A family of four could have legally held over $\$ 455,000$ in tax-free saving vehicles. Further, there was widespread evidence of abuse of this system, with accounts being held in fictitious names. Nagano (1988) estimates that over 70 percent of all personal saving took advantage of these tax-exempt vehicles, with $¥ 13.5$ trillion ( $\$ 110$ billion) escaping the tax base.

The tax-exempt saving system was abolished in the 1987 reform, except for those deemed truly to need social assistance (the elderly, single-parent families, and the handicapped). It has been replaced with a flat tax on all interest income (withheld at source) of 20 percent, with 15 percent collected for the national government and 5 percent as local taxes.

The second tax advantage offered on interest income is separate taxation. Even before 1987, interest received on saving deposits and similar accounts (other than tax-exempt ones) was subject to a separate 20 percent withholding tax at source and then could be excluded from taxable income in filing a return. For other forms of interest income (bond interest, and so on) the taxpayer could aggregate it with taxable income or pay a separate tax of 35 percent. None of interest income was subject to the marginal rates, ranging up to 70 percent, shown in the rate schedule. This separate taxation option will remain available if the present reform package is adopted.

The taxpayer also has the option of separate taxation of dividend income. Again, this effectively shields the dividend recipient from the highest marginal tax rates in Table 2 . For dividends, the marginal rate for the optional separate taxation is 35 percent, as long as the recipient owns less than 5 percent of the outstanding equity and as long as the amount of dividends received from that corporation is less than $¥ 500,000$ (roughly \$4000). Rich investors can avoid these limits through diversification. However, separate taxation is unavailable on the dividends of closely held corporations. For small dividends, there is an even better treatment. If an individual receives a dividend of less than $¥ 100,000$ (\$800) from a company (excluding mutual funds), he or she may elect separate taxation at the marginal rate of 20 percent.

In addition to the advantages of separate taxation, dividends are lightly taxed at the individual level due to another feature of the individual tax law. For taxpayers with ordinary taxable income of less than $¥ 10$ 
million $(\$ 81,300)$, a tax credit amounting to 10 percent of dividends received is allowed. For those with higher taxable incomes, the credit is reduced, although it always exceeds 5 percent. The basic 10 percent credit means that the maximum marginal rate of national-level taxation of dividends (under separate taxation) is effectively 25 percent (10 percent for small dividends).

Capital gains on securities are not taxed in Japan, although the current proposal would change this. It would give taxpayers the option of paying a tax equal to 1 percent of the value of the stock transaction or paying a separate tax on the actual gain, at the rate of 20 percent. The 1-percentof-sales-value option implies that capital gains on securities will still be very lightly taxed in Japan relative to their current treatment in the U.S. (fully taxable at ordinary rates upon realization). Capital gains on land and buildings are taxed separately in Japan, with the terms depending on the holding period.

Before the 1987 tax reform, corporate capital return was extremely lightly taxed at the personal level in Japan. Most interest income completely escaped taxation, as did all capital gains on securities. Dividends had the option of separate taxation and thus escaped the marginal rates, which went as high as 70 percent. If the Ministry of Finance proposal is adopted, this will change substantially. Almost all interest income will be separately taxed, at a 20 percent rate. However, capital gains will still be lightly taxed, and dividends will still be eligible for a tax credit and optional separate taxation at a 35 percent rate.

The general outline of the corporate income tax in Japan is not terribly different from that in the United States. As in our country, the tax base is corporate profits, or the excess of gross revenue over total costs. Included in costs are the interest payments on debt obligations (both bonds and bank loans). In other words, interest expenses are deductible, as in the United States. The corporate tax is approximately a flat-rate system (also as in the United States), with slightly lower rates applying only to very small corporations.

The Japanese corporation income tax differs from the American one in its treatment of dividends paid and intercorporate dividends. The current Japanese tax system attempts to partially offset the double taxation of corporate equity income by taxing dividends paid at a lower rate than retained earnings. The current national rates are 42 percent for retained earnings and 32 percent for dividends paid (reduced in 1987 from 43.3 and 33.3 percent, respectively). The effective rates, including local taxes, are approximately 55 and 45 percent, respectively. The Ministry of Finance estimates the overall marginal corporate tax rate on equity income as 51.55 percent in 1988 (down from 52.92 percent in 1986). This com- 
pares with their estimate of the U.S. rate (including state corporation income taxes) of 40.34 percent.

The current reform proposal would phase out this separate treatment of dividends and returned earnings. It proposes that the national corporation income tax rate be set at 37.5 percent for 1990 and beyond. While this is only slightly higher than the U.S. corporate rate of 34 percent, the difference widens when one takes state- and local-level taxation into account. The Ministry of Finance estimates that the total Japanese corporate rate would be 49.99 percent under their proposals, compared with the U.S. figure of 40.34 percent.

Unlike the U.S. tax system, the Japanese corporation income tax has always exempted intercorporate dividend income from the tax base, thus avoiding double taxation. However, the new proposal adopts the U.S. practice of partial taxation of dividends received by a corporation. It proposes including 10 percent of corporate dividends received in the corporate tax base in 1989, with 20 percent (the U.S. figure) inclusion in 1990 and thereafter.

The Japanese tax system permits several types of tax-free reserves that share to reduce reported corporate earnings and, therefore, taxes. These reserves include (1) the reserve for bad debts, (2) the reserve for returned goods, (3) the reserve for employee bonus payments, (4) the reserve for retirement allowances, (5) the reserve for repairs and product guarantees, and (6) the reserve for overseas market development for small and medium-sized corporations. In 1986, the reserve fund for price fluctuation was abolished. ${ }^{1}$

It is the interaction of the Japanese corporation and individual income tax that can create very low effective taxation of corporate capital income. Given that the corporate statutory rate is relatively high and the individual rates on interest relatively low, interest payments are in effect subsidized. The cost to a corporation of making a 10 percent interest payment will be roughly 5 percent if the new proposed rate structure is adopted. On the other hand, the investor will receive 8 percent (after the 20 percent tax). This net subsidy clearly reduces the cost of capital. It also is less effective at lower nominal interest rates.

\section{THE PRESSURES FOR REFORM}

The preceding section described most of the elements of the enacted and proposed tax reform. Those include virtual elimination of the tax-free

1 As something of an aside, it might be noted that these reserve accounts lower corporate earnings and may partially explain the traditionally high price-to-earnings ratios on Japanese equity securities. 
saving system, except for people in special circumstances; reducing the number of brackets and the highest rates for the individual income tax; raising the threshold income levels of the individual income tax; lowering the basic rate of the corporation income tax and eliminating the different treatment of dividends paid and retained earnings; curtailing the use of corporation reserve accounts; and introducing a tax on intercorporate dividends.

There is one additional major component of the proposed tax reform. That is the introduction of a new consumption-type value-added tax. The current proposal is for a broad-based 3 percent tax with very limited exemptions. There would be an exemption for very small enterprises (sales less than $\$ 240,000$ ) and a simplified procedure available to small and medium-sized firms (sales under $\$ 4$ million). A large number of specific excise taxes (commodity tax, playing-cards tax, sugar excise tax, admission tax, travel tax, electricity tax, and timber delivery tax, among others) would be repealed. The commodity tax currently applies to a number of luxury goods. However, in an economy as dynamic as Japan's, many of the taxed items (for example, air conditioners, television sets, and refrigerators) are no longer appropriately considered luxuries.

There are a number of separate pressures for Japanese tax reform that can be identified. These include compliance problems with the existing tax system and a widespread feeling that it is unfair; international trade frictions and pressures encouraging the Japanese to adopt a more proconsumption tax system; concern about the international mobility of factors, particularly capital and entrepreneurs, in the face of a Japanese system with comparatively high marginal tax rates; projections that government revenue will need to expand significantly to deal with the rapid growth of the retired population; and concern that corporate tax revenue would be jeopardized (through transfer pricing and financial arbitrage) unless the Japanese corporation income tax is roughly harmonized with the recently changed U.S. tax system.

\subsection{Compliance Problems and Fairness Considerations}

Fairness issues are probably the biggest motivator of the Japanese reform movement. The same may well have been true in the U.S. One very important aspect of the Japanese compliance and fairness problem is referred to as $10-5-3$, or sometimes 9-6-4. These numbers refer to the fact that it is commonly believed that $90-100$ percent of the income of workers is subject to tax but only 50-60 percent of business income (particularly the income of small businesses) is reported and only 30-40 percent of farm income is subject to tax. This widely perceived inequality has been documented in the research of Ishi (1984) and Honma (1984). 
The problem is thought to have grown worse in the past twenty years (Noguchi, 1988). The introduction of a value-added tax (VAT) is intended to help this 10-5-3 problem in two ways: First, the required record keeping and invoice reporting will improve income reporting for the income tax. And, second, the VAT itself will be borne by all consumers relatively evenly.

A second aspect of the compliance problem is that there is no taxpayer identification scheme (similar to the U.S. social security number or taxpayer identification number) in Japan. This facilitated the abuse of the Maruyu saving system and adds to the general impression that the wealthy can conceal income from taxation. There has been tremendous political opposition to the introduction of an identification system. The result has been increasing use of a withholding-at-source system (now for interest income as well as wages, and proposed for capital gains). It is hoped that the combination of withholding taxes and a VAT will considerably improve the fairness of the Japanese tax system.

\subsection{The Aging Society}

The Japanese position in Table 1 as the least-taxed major country in the Organization for Economic Cooperation and Development (OECD) is largely due to its relatively light social security burden. Japan has one of the lowest fractions of the populations that is elderly, but it also is aging more quickly than any other major economy. The upper panel of Table 4 shows that the number of people of working age per elderly person in Japan is projected to fall from 5.9 in 1985 to 2.3 in 2020. This ratio is, of course, of utmost importance for pay-as-you-go national retirement schemes such as those in Japan and the U.S. Some of the expenses of Japanese social security coverage are paid for out of general revenue, and the expectation is that the reliance on general revenue will have to be increased. The lower panel of Table 4 shows that while Japan had the lowest fraction of elderly in their population between 1950 and 1985, by 2000 their elderly fraction will be more than 30 percent greater than in the U.S. By 2020, they will have the highest fraction of elderly of the five countries shown. It is projected that the fraction of the Japanese population over sixty-five will be more than twice the fraction that are currently elderly in either the U.S. or Japan. The 28 percent total tax load shown in Table 1 is expected to rise to about 50 percent, unless the design of the social security system is altered. The proposed new VAT, which would be introduced with an initial 3 percent rate, is thought to have the potential to become a major contributor to the revenue necessary for dealing with the aging population. If this is to be so, of course, it will be necessary to raise the tax rate markedly. 


\section{TABLE 4}

The Aging of Japan

\begin{tabular}{lcccr}
\hline & 1985 & 2000 & 2010 & 2020 \\
\hline $\begin{array}{l}\text { Ratio of working age population } \\
(20-64) \text { to elderly population } \\
(65+)\end{array}$ & 5.9 & 3.7 & 2.8 & 2.3 \\
\hline
\end{tabular}

Ratio of elderly (65 and over) to total population (in percent)

\begin{tabular}{lrrrrr}
\hline & 1950 & 1970 & 1985 & 2000 & 2020 \\
\hline Japan & 4.9 & 7.1 & 10.3 & 16.3 & 23.6 \\
West Germany & 9.4 & 13.2 & 14.5 & 16.7 & 21.2 \\
France & 11.4 & 12.9 & 12.4 & 14.7 & 18.0 \\
United Kingdom & 10.7 & 12.9 & 15.1 & 15.3 & 17.8 \\
United States & 8.1 & 9.8 & 11.7 & 12.0 & 15.4 \\
\hline
\end{tabular}

Source: Watanabe (1988), p. 13.

\subsection{Labor Supply and the Brain Drain Fear}

Reducing the progressivity of the individual income tax is an important and intentional element of the Japanese tax reform. Noguchi (1988) reports that high-salaried workers whose incomes are roughly $¥ 10$ million $(\$ 81,300)$ or more have been exerting strong political pressure for relief. This pressure was increased by the flattening of the marginal tax rate schedules in both the U.S. and the U.K.

There has been little opposition to lowering the top marginal rates. Due to the possibilities for separate taxation, they are only applicable to the high salaries of top executives, entertainers, athletes, and so on. There seems to be concern about the labor-supply effects of the high tax rates. More pointedly, there is concern about the location decisions of high-tech international firms. Hasegawa (1988) states that "the burden it (the Japanese tax system) imposes on high-income earners is undeniably an impediment to the flow of elite business personnel into Japan." He feels that Japanese businesses now are trying to lure highcaliber foreign talent to Japan but that they are finding both traditional labor practices and the tax systems to be severe handicaps. Further, he worries about a "brain drain" away from Japan, as executives find that they can locate facilities abroad with lower labor costs and more attractive tax environments. 


\subsection{Financial Arbitrage and Transfer Pricing}

At least as worrisome as a loss of highly skilled labor (or an inability to attract top talent to Japan) is a possible capital outflow due to Japan's relatively steep corporate tax rate. With the U.K.'s reduction of its statutory corporate rate from 45 to 35 percent in 1986 and the U.S.'s lowering of its rate from 46 to 34 percent, many Japanese are worried about their international competitive position with respect to this tax.

The problem of having a high statutory corporate rate is not only that capital will locate elsewhere but also that reported domestic profits of international companies may be transferred abroad. Multinational companies have a strong incentive to borrow in countries with high tax rates in order to lower equity profits there. Further, the use of internal transfer pricing can shift reported profits from higher-rate countries to those with lower rates. It is possible that high corporate rates thus become counterproductive in terms of generating revenue. This type of argument, and the concerns of transfer pricing and international borrowing, have been major pressures for lowering corporate rates in Canada as well as in Japan.

If the current reform is adopted, Japan, the U.S., and the U.K. will have very similar rates of corporate taxation at the national level. The rates will range from 34 to 37.5 percent. Such a narrow range probably stops most accounting practices designed solely for relocating profits.

\section{THE EFFECTIVE RATE OF TAXATION ON CORPORATE CAPITAL INCOME}

My earlier work with Tachibanaki (Shoven and Tachibanaki, 1988) found that the Japanese government got a very small percentage (4.4 percent) of the return on domestically financed incremental investments in 1980, while the investor (on average) got 95.6 percent of the return. In this section, the methodology that gave us that finding is summarized and the results are recalculated for 1985 and for the 1988 proposed reform package. The new results differ dramatically from those of the earlier study.

The Shoven and Tachibanaki study used the same methodology as King and Fullerton (1984). What is examined is the total tax wedge between the return of an incremental investment and the return realized by the investor or financier. The approach takes into account both company-level taxation and personal-level taxation.

In this paper I use exactly the same methodology. In fact, I use the PTAXJAP software made available by Mervyn King. This software 
adapts the King-Fullerton approach to the Japanese tax system and was used in King (1987). The input tax parameters are those I developed with Tachibanaki, appropriately updated to 1985 and to reflect the reform proposal.

As in Shoven and Tachibanaki (1988) and King and Fullerton (1984), the tax wedge and effective tax rate are calculated separately for different types of assets, financial instruments, industries, and types of investors. Three types of assets (machinery, buildings, and inventories), three financial instruments (debt, retained earnings, and new equity issues), three industries (manufacturing, commerce, and other, which is mostly construction, transportation, communications, and utilities), and three classes of investors (households, tax-exempt institutions, and insurance companies) are distinguished. All told, then, there are three possibilities in each of four categories, which means that there are 81 different combinations. All investments are assumed to earn a real return of 10 percent. The software calculates the net return earned by the investor for each of the eighty-one combinations, as well as the total taxes collected for each. Features of the tax law that are taken into account include accelerated depreciation, inventory accounting, investment tax credits, the deductibility of interest payments from the corporate income tax, the treatment of capital gains, and the interaction of taxation and inflation in the tax system.

Table 5 contains the effective tax rate (the tax wedge divided by the gross real return) results for Japan for 1985. The figures are calculated for three rates of inflation, 0 percent, 5 percent, and 10 percent. The figures in each row refer to the average marginal tax wedge for 27 different combinations of investment flows. For example, the number for "machinery" with 5 percent inflation is 18.9 percent. This is the average marginal tax wedge for machinery investments in three different industries, using three sources of finance, and for three different classes of owners. Similarly, the number for debt ( -28.6 percent) is the average for three types of debt-financed assets in three industries with three different classes of owners. The pattern shown in Table 5 for 1985 is quite similar to the results in Shoven and Tachibanaki (1988) for 1980. Both sets of results show that the overall effective marginal tax rate was low at 10 percent inflation but substantially higher at lower rates of inflation. The main reason for this inflation effect is that the effective tax rate on debtfinanced investments declines rapidly as nominal interest rates rise. In 1985 Japan had a total (national plus local) corporate tax rate of 57 percent for retained earnings. Given that interest payments were deductible from this tax and were very lightly taxed at the individual level, a net subsidy resulted for debt-financed investments. The effective tax rate for 
TABLE 5

Effective Marginal Tax Rates (percent) in Japan, 1985

\begin{tabular}{lrrr}
\hline & & Inflation rate & \\
\cline { 2 - 4 } & Zero & Five & Ten \\
\hline Asset & & & \\
Machinery & 23.0 & 18.9 & 10.0 \\
Buildings & 27.2 & 18.4 & 3.9 \\
Inventories & 39.6 & 23.0 & 6.2 \\
Industry & & & \\
Manufacturing & 30.2 & 23.8 & 13.8 \\
Other industry & 24.0 & 10.4 & 7.6 \\
Commerce & 35.0 & 23.3 & 9.7 \\
Source of finance & & & \\
Debt & 2.9 & -28.6 & -64.8 \\
New share issues & 57.6 & 72.2 & 67.7 \\
Retained earnings & 51.9 & 60.8 & \\
Owner & & & -7.6 \\
Households & 23.8 & 9.9 & 78.8 \\
Tax-Exempt investors & 26.6 & 15.1 & 7.0 \\
Insurance companies & 57.8 & 70.0 & \\
Overall & 29.6 & 20.1 & \\
\hline
\end{tabular}

equity-financed investments actually rises with inflation, primarily due to unindexed depreciation deductions.

Despite the fact that the pattern of the numbers in Table 5 is similar to those for 1980, the "best guess" effective marginal rate of taxation on corporate investments in Japan changed considerably between 1980 and 1985. Shoven and Tachibanaki (1988) estimated the overall figure to be 4.4 percent in 1980 . However, that result depended on a specification of the expected rate of inflation, which was taken as the average of the inflation rates experienced in the 1970s (9 percent). By 1985, Japan had experienced several years of 2 percent inflation. If that is taken as the expected rate of inflation, the overall tax rate for 1985 is about 26 percent.

The effective tax rate calculations for the current proposal are shown in Table 6 . The increased tax on interest income, the reduced corporate tax rate, the elimination of the differential between retained earnings and dividends, and the new capital gains tax on profits on securities are all captured in the model. The tax reform would slightly increase the effective corporate tax rate at zero inflation and would make the tax rate much less sensitive to inflation. The large potential subsidy to debtfinanced investments is largely eliminated by the reduction in the statu- 
TABLE 6

Effective Marginal Tax Rates in Japan under the 1988 Tax Proposal (percent)

\begin{tabular}{lccr}
\hline & \multicolumn{3}{c}{ Inflation rate } \\
\cline { 2 - 4 } & Zero & Five & Ten \\
\hline Asset & & & \\
Machinery & 26.5 & 27.8 & 25.7 \\
Buildings & 30.1 & 28.2 & 22.2 \\
Inventories & 39.7 & 32.3 & 24.5 \\
$\begin{array}{l}\text { Industry } \\
\text { Manufacturing }\end{array}$ & & & \\
Other industry & 31.9 & 31.5 & 28.3 \\
Commerce & 28.0 & 23.2 & 15.4 \\
Source of finance & 36.0 & 32.1 & 26.3 \\
Debt & & & \\
New share issues & 13.5 & -2.1 & -2.1 \\
Retained earnings & 57.3 & 75.0 & 91.2 \\
Owner & 46.5 & 54.7 & 60.2 \\
Households & & & \\
Tax-exempt investors & 27.3 & 21.9 & 13.9 \\
Insurance companies & 23.6 & 15.8 & 5.3 \\
Overall & 54.7 & 67.7 & 24.0 \\
\hline
\end{tabular}

tory corporate tax rates and by the increase in the taxation of interest income at the individual level.

The "best guess" overall effective tax rate for new corporate investments in Japan after the implementation of the 1988 tax reform proposals is 31.8 percent. The reason that this number is chosen from the bottom row of Table 6 is that there is now a remarkable degree of price level stability in Japan. Consumer prices rose 0.6 percent in 1986 and 0.1 percent in 1987, and they are expected to increase about 0.4 percent in 1988.

The overall conclusion that I draw from Tables 5 and 6 is that the effective rate of taxation of new investment in Japan has risen substantially since 1980 . Most of that increase has taken place because of the elimination of inflation. The tax reform itself would increase the effective tax rate slightly (at 0 percent inflation) and take a major stride in making the system less sensitive to inflation, should it return. The tax incentives for debt, while still considerable, would be substantially reduced.

The effective tax rate faced by Japanese investors on domestic corporate investments remains lower than the effective tax rate faced by American investors on U.S. corporate investments. The difference has 
narrowed, however. Fullerton (1987) found that at 4-percent inflation, the 1986 tax reform raised the overall U.S. effective tax rate on new corporate investment from 29.4 percent to 41.1 percent. The U.S. tax reform's main accomplishment in this area was evening the treatment of different corporate assets (for example, plant versus equipment) by eliminating the investment tax credit on equipment and by adjusting depreciation lifetimes. Tables 5 and 6 indicate that the differences across asset type were not great in Japan even before their reform. What neither country has addressed is the substantial difference between the treatment of owner-occupied housing and corporate capital investments.

\section{CONCLUSION}

The Japanese tax reform proposals are extremely significant. The probable changes in the system are at least as fundamental as those contained in the U.S. 1986 Tax Reform Act. The taxation of the formerly tax-free savings accounts, the introduction of a tax on security capital gains, and the adoption of a VAT will greatly improve the perception of fairness of the system. The VAT is likely to be the tax vehicle that will permit Japan to finance its rapidly growing dependent elderly population. And a combination of several elements in the reform as well as the almost complete absence of inflation may cause the effective tax rate on corporate capital income to increase to a point where it is comparable, although still lower, than the corresponding U.S. figure. The reforms of 1987 have already reduced the tax system's bias toward debt and made its effects on investment incentives less dependent on the rate of inflation.

\section{REFERENCES}

Fullerton, Don. 1987. The indexation of interest, depreciation, and capital gains and tax reform in the United States. Journal of Public Economics 32:25-51.

Hasegawa, Keitaro. 1988. Tax reform from a global perspective. Japan Echo 15:4649.

Honma, Masaaki, Ihori Toshihiro, Atodi Masumi, and Murayama Junki. 1984. Shotokuzei Futan no Gyoshukan Kakusa (Interoccupational inequality of income tax burden). Kikan Gendai Keizai 59:14-25.

Ishi, Hiromitsu. 1984. Zaisei Kaikaku no Ronri (The logics of fiscal reconstruction). Nihon Keizai Shinbunsha.

King, Mervyn. 1987. The Japanese tax reform proposals. London School of Economics, mimeo.

King, Mervyn, and D. Fullerton. 1984. The taxation of income from capital: A comparative study of the United States, the United Kingdom, Sweden, and West Germany. Chicago: University of Chicago Press. 
Ministry of Finance. 1986. An outline of Japanese taxes. Printing Bureau, Ministry of Finance, under authorization of Tax Bureau, Tokyo.

Nagano, Atushi. 1988. Japan. In World tax reform: $A$ progress report, ed. Joseph A. Pechman. Washington, D.C.: The Brookings Institution, 155-61.

Noguchi, Yukio. 1988. Tax reform debates in Japan. Hitotsubashi University (Tokyo), mimeo.

Pechman, Joseph A. 1988. Introduction. In World tax reform: A Progress report, ed. Joseph A. Pechman. Washington, D.C.: The Brookings Institution, 1-14.

Pechman, Joseph A., and K. Kaizuka. 1976. Taxation. In Asia's new giant, eds. H Patrick and H. Rosovsky. Washington, D.C.: The Brookings Institution.

Shoven, John B., and Toshiaki Tachibanaki. 1988. The taxation of income from capital in Japan. In Government policy towards industry in the United States and Japan, ed. John Shoven. Cambridge: Cambridge University Press. 51-96.

Watanabe, Hiroshi, ed. 1988. Reports by Tax Commission on Tax Overhaul Ministry of Finance, Tokyo. 